\title{
AKCJE WYSIEDLEŃCZE UKRAIŃCÓW-ŁEMKÓW W POLSCE W LATACH 1944-1950
}

Wysiedlenie ludności łemkowskiej i wszystkich Ukraińców mieszkających w Polsce w latach 1944-1950 było konsekwencją polityki narodowej komunistycznych władz Polski. Ich celem było przekształcenie Polski w państwo mononarodowe. Podstawowym sposobem osiągnięcia tego celu było zmuszenie mniejszości narodowych do opuszczenia Polski i zastosowanie środków asymilacyjnych wobec pozostałych. Dlatego w 1947 r. przeprowadzono akcję „Wisła”, w ramach której deportowano pozostałych Ukraińców-Łemków na tereny zachodnie i północne Polski i poddano ich asymilacji.

Słowa kluczowe: Ukraińcy, Łemkowie, deportacje, Polska 1944-1950

Polska mimo przesunięcia jej terytorium po II wojnie światowej ze wschodu na zachód, nadal była państwem wielonarodowościowym. Jej obszar nadal zamieszkiwali Białorusini, Litwini, Słowacy, Ukraińcy i Żydzi, co prawda w znacznie mniejszej liczbie niż przed wojną, oraz Niemcy, których liczebność znacznie wzrosła ze względu na włączenie do Polski terenów, które wcześniej wchodziły w skład III Rzeszy Niemieckiej. Przed ekipą komunistyczną w Polsce, która w oparciu o Armię Czerwoną, przejęła w niej rządy, stanął problem opracowania polityki narodowościowej. Rozważano dwie możliwości. Pierwszą - zagwarantowanie praw mniejszościom narodowym, chociaż dokładnie nie precyzowano, o jakie swobody chodzi oraz drugą - przekształcenie Polski w państwo jednonarodowe. Ostatecznie górę wzięła ostatnia koncepcja. Sprzyjało temu stanowisko władz radzieckich, które opowiadały się za wymianą ludności między Polską a radzieckimi republikami: Białoruską, Litewską i Ukraińską, jak również decyzja o wysiedleniu z Polski Niemców.

Dnia 9 września 1944 r. z inicjatywy Kremla Polski Komitet Wyzwolenia Narodowego, który był komunistyczna namiastką przyszłego polskiego rządu, oraz również marionetkowy rząd Ukraińskiej Socjalistycznej Republiki Radzieckiej podpisały układ, zwany też umową, w 
którym obie strony zobowiązały się do przesiedlenia (oficjalnie użyto terminu „ewakuacja”) z Polski .wszystkich obywateli narodowości ukraińskiej, białoruskiej, rosyjskiej i rusińskiej”, jak również przystąpić do przesiedlenia z ZSRR wszystkich Polaków i Żydów będących obywatelami polskimi do 17 września 1939 roku $^{1}$. W układzie zaznaczono, że przesiedlenie ma mieć charakter dobrowolny, w związku z czym wykluczano stosowanie przymusu bezpośredniego, jak i pośredniego ${ }^{2}$.

Realizacja zawartego układu postawiła ludność ukraińską przed dylematem: pozostać albo zdecydować się na wyjazd. Niektórzy opowiedzieli się za opuszczeniem dotychczasowej ojczyzny. Konflikt polsko-ukraiński okresu II wojny światowej, utrata bliskich oraz dorobku całego życia, stwarzało u nich przekonanie o niemożliwości ułożenia $\mathrm{w}$ przyszłości dobrosąsiedzkich stosunków z Polakami. Wyjechała także część tych, którzy nie godzili się na polską przynależność państwową ich rodzinnej ziemi. Dali temu wyraz w petycjach kierowanych na ręce I sekretarza Komitetu Centralnego Komunistycznej Partii (bolszewików) Ukrainy Nikity Chruszczowa oraz Józefa Stalina jeszcze na przełomie lipca i sierpnia 1944 r., w których prosili o przyłączenie ich miejscowości do USRR ${ }^{3}$. Zaznaczyć należy, że nadsyłanie tych petycji mogło być inspirowane przez kierownictwo USRR, które opowiadało się za przyłączeniem do Ukrainy radzieckiej Chełmszczyzny, Łemkowszczyzny i Podlasia ${ }^{4}$. Niemniej można przyjąć, że z wymienionych powodów na początku akcji przesiedleńczej do

\footnotetext{
${ }^{1}$ Archiwum Akt Nowych w Warszawie (AAN), Główny przedstawiciel Rządu RP do Spraw Ewakuacji Ludności Ukraińskiej z Polski w Lublinie, syg. 397/1. Układ między PKWN a rządem USRR w sprawie przesiedlenia ludności z 9 września 1944 r. Patrz: Pisuliński J., Przesiedlenie ludności ukraińskiej z Polski do USRR w latach 1944-1946, Rzeszów 2017.

2 Niektóre tezy dotyczące wysiedleń do ZSRR były prezentowane na międzynarodowej konferencji naukowej: „Łemkowszczyzna w lalach 1939-1947. Wojna, okupacja i wysiedlenia" Kraków, maj 2001

${ }^{3}$ Deportacji. Zachidni zemli IJkrajiny kincia 30-ch - początku 50-ch rr. Dokumenty, materiały, spohady. T. I. 1939-1945 rr., Lviv 1996, dok. 91-98, s. 272-278.

${ }^{4}$ I. Kozłowśkyj, Wstanowłennia ukrajinśko-polśkoho kordonu 1941-1951 rr. Lviv 1998, s. 106-107.
} 
grudnia 1944 r. wyjechało około 20 tys. osób ${ }^{5}$. Po przejściu frontu, wiosną 1945 r. z Łemkowszczyzny wyjechała część ludności z rejonu Przełęczy Dukielskiej i Łupkowskiej, zniszczonych działaniami wojennymi ${ }^{6}$. Wyjechali także niektórzy mieszkańcy wsi: Biała Woda, Czarna Woda, Jaworki i Szlachtowa (pow. Nowy Targ), którzy w marcu 1945 r. napisali petycję, w której prosili Radę Najwyższą USRR oraz N. Chruszczowa o przesiedlenie ich na Ukrainę 7 .

Większość ludności ukraińskiej, w tym łemkowskiej zdecydowała się na pozostanie. Tego postanowienia nie zmieniła nawet intensywna i kłamliwa propaganda radziecka, która przedstawiał Rosję radziecką jako kraj mlekiem i miodem płynący ${ }^{8}$. Decydowały o tym różne względy, wśród których najważniejsze było przywiązanie do ojcowizny. Traktowano ją jak ojczyznę, utożsamianą nie tylko $\mathrm{z}$ miejscem urodzenia, ale ich stałej bytności, zaznaczoną licznymi śladami ich życia, kultury i działalności (cerkwie, groby bliskich, kapliczki, przydrożne krzyże, placówki kulturalno-oświatowe, sady, uprawne pola, lasy itp.). Wszystko to umacniało poczucie przywiązania do rodzinnej ziemi - swoich stron. Poza tym nadchodzące wieści o radzieckiej rzeczywistości zniechęcały do wyjazdu. Poza tym część ludności ukraińskiej miała przykre doświadczenia z czasów pierwszej okupacji radzieckiej, czyli lat 1939-1941, kiedy to objęto ich represjami oraz kolektywizacją rolnictwa.. Przesiedlenie do USRR mogło oznaczać tylko pogorszenie warunków bytowych. Do pozostania wzywała także Ukraińska Powstańcza Armia. Co prawda na Łemkowszczyźnie zachodniej nie miała ona takich wpływów, jak na Łemkowszczyźnie wschodniej, lecz przytaczana przez nią argumentacja za pozostaniem mogła to przekonanie umacniać. W wydanej przez UPA ulotce pt. „Do mieszkańców Łemkowszczyzny” wzywano: „Nie wychodźcie z ziemi Waszych Przodków, oni te ziemie ochraniali przed wiekami. Ochraniali je przed Tatarami. Każdy tu kamień, krzyż, mogiła mówi

5 A. B. Szczęśniak, W Z. Szota, Droga do nikąd. Działalność Organizacji Ukraińskich Nacjonalistów i jej likwidacja w Polsce, Warszawa 1973, s. 223.

${ }^{6}$ Repatriacja czy deportacja. Przesiedlenie Ukraińców z Polski do USRR 1944-1946. T. I. Dokumenty 1944-1945. Pod red. E. Misily, Warszawa 1996, s. 11.

${ }^{7}$ Ibidem, dok. 29, s. 90-91.

${ }^{8}$ B. Halczak, Dzieje Łemków od średniowiecza do czasów współczesnych, Warszawa 2014, s. 161. 
językiem wielu wieków. A Wy chcecie opuścić te ziemie? Chcecie rzucić wszystkie świętości? Chcecie porzucić to piękno gór, lasów, piękno Waszych marzeń? Czy Wam tego nie żal? Chcecie zostawić Wasze cerkwie? Chcecie odejść ze Świętej Ziemi? Wy nie dajcie się okłamać. Nie ściągajcie na siebie przekleństwa, brońcie Waszej ziemi i Waszych chat. Nigdzie nie szukajcie szczęścia i zostańcie tutaj. Lepiej jest zginąć niż rzucić swoją ziemię rodzinną"

Rezygnując z wyjazdu, ludność ukraińska zaczęła organizować sobie w nowych warunkach życie kulturalno-oświatowe. Zaczęły powstawać komitety ukraińskie, które zajęły się m.in. organizacją szkolnictwa ukraińskiego. Na przełomie stycznia-lutego 1945 r. utworzono w Gorlicach Włościańsko-Robotniczy Komitet Łemkowszczyzny. Wkrótce komitety takie powstały w Nowym Sączu i prawdopodobnie w Jaśle ${ }^{10}$. Te dwa ostatnie nie uzyskały zgody władz na rozpoczęcie działalności. W lutym komitet gorlicki otrzymał zgodę Ministerstwa Oświaty na organizowanie szkół z ukraińskim językiem nauczania. Do końca kwietnia uruchomiono 48 takich placówek oraz podjęto starania o reaktywowanie, powstałego w czasie okupacji niemieckiej, Seminarium Nauczycielskiego w Krynicy. Poza tym komitet wzywał Łemków do wstępowania w szeregi Armii Czerwonej. W czerwcu Komitet zaprzestał działalności, a we wrześniu rozwiązano wszystkie szkoły ukraińskie, co wynikało z toczącej się akcji wysiedleńczej, która wówczas nabrała już wyraźnego przymusu ${ }^{11}$.

O tym, że większość ludności ukraińskiej, w tym łemkowskiej, chciała pozostać i dążyła do normalizacji życia, świadczą postulaty zgłoszone pod adresem władz przez jej przedstawicieli z województwa krakowskiego, lubelskiego i rzeszowskiego w dniu 24 lipca 1945 r. Na konferencji w Ministerstwie Administracji Publicznej Jan Andrasz, Michał Doński i Piotr Dutka, którzy reprezentowali Łemkowszczyznę, wysunęli zbieżne do pozostałych delegatów postulaty. Sprowadzały się one m.in. do zagwarantowania swobód religijnych, utworzenia szkół podstawowych i

\footnotetext{
${ }^{9}$ Repatriacja czy deportacja...., T. I, dok. 34, s. 102.

${ }^{10}$ Archiwum Państwowe w Krakowie (APK), KW PPR, syg. 821. Protokół z zorganizowanego zebrania założycielskiego Włościańsko-Robotniczego Komitetu Łemkowszczyzny na powiat Nowy Sącz z 19 marca 1945 r.

${ }^{11}$ Repatriacja czy deportacja..., 1.1, dok. 34, s. 100.
} 
średnich, umożliwienia młodzieży „ruskiej” studiowania w szkołach wyższych, zezwolenia na prowadzenie spółdzielni i otwarcia banku „ruskiego”, przeprowadzenia komasacji gruntów oraz przydzielenie ludności „ruskiej” ziemi opuszczonej przez ludność „ruską’ objęcia reformą rolną. Ponadto domagano się anulowania dekretu zabraniającego ludności „ruskiej” sprzedaży nieruchomości, amnestii dla „wrogów politycznych”, pozwolenia na założenie partii demokratycznej, nie dyskryminowania zawodowego „Rusinów” oraz zmiany stosunku niektórych organów administracji publicznej do ludności „ruskiej”"12.

Władze dalekie były od realizacji powyższych postulatów. Celem konferencji było bowiem uświadomienie ludności ukraińskiej, poprze jej przedstawicieli, o nieuchronności przesiedlenia i przekonać ją do wyjazdu. Jednak mimo tych zabiegów, ludność nadal chciała pozostać na swych gospodarstwach. Nie przynosił zamierzonego efektu stosowany przymus administracyjny i ekonomiczny, co stało w sprzeczność z oficjalnie przyjętą zasadą dobrowolności przesiedlenia. Na ludność która uchylała się od wyjazdu, nałożono oraz ściągano zaległe podatki, wyznaczano kontyngenty, zmuszano do pracy na gruntach połemkowskich itp. ${ }^{13}$. W tej sprawie miejscowe władze wydawały odpowiedni zarządzenia. Na przykład starosta nowosądecki Józef Łabuz nakazał wysiedlić Łemków z pasa nadgranicznego, ściągać świadczenia rzeczowe na rzecz państwa od nie wyjeżdżających oraz nakłaniać ich d wyjazdu. Jeżeli nie odniosłoby to rezultatu, przewidywał „zastosowani wszelkich środków przymusu, przysługujących szefowi administracji publicznej"14.

Wymienione środki nacisku nie doprowadziły do całkowitego przesiedlenia się ludności. Do 15 sierpnia 1945 r., według danych głównego przedstawiciela rządu RP do spraw ewakuacji J. Bednarza (moim zdaniem można je traktować jedynie orientacyjnie) z województwa lubelskiego wyjechało $66,4 \%$ osób podlegających akcji, z rzeszowskiego $28 \%$, a z

\footnotetext{
${ }^{12}$ Ibidem, dok. 61, s. 155-158.

${ }^{13}$ Ibidem, dok. 68, s. 172-173

${ }^{14}$ Archiwum Ministerstwa Spraw Wewnętrznych i Administracji (obecnie Archiwum Instytutu Pamięci Narodowej w Warszawie) (AMSWiA), MAP, syg. 304. Pismo starosty nowosądeckiego J. Łabuza do Urzędu Wojewódzkiego w Krakowie w sprawie przesiedlenia ludności ukraińskiej z 20 sierpnia 1945 r.
} 
krakowskiego 55,6\%. W niektórych powiatach zamieszkałych przez Łemków odsetek ten przedstawiał się następująco: powiat gorlicki - 70,\%, jasielski $91,2 \%$, nowosądecki $-55,6 \%$ i sanocki $-27 \%{ }^{15}$.

W tej sytuacji władze zdecydowały się na deportację pozostałej ludności, przy użyciu oddziałów wojskowych. 3 września 1945 r. na teren południowo-wschodniej Polski zostały skierowane 3. 8. i 9. DP, celem dokonania wysiedlenia ludności. 25 września 1945 r. starosta nowosądecki J. Łabuz, powołując się na $\S 7$, punktu 5, ustęp 2 rozporządzenia Ministra Spraw Wewnętrznych z dnia 22 stycznia 1937 r., nakazał Łemkom opuścić w przeciągu 14 dni strefę nadgraniczną, grożąc jednocześnie osobom, które nie zastosowałyby się do tego rozporządzenia, „usunięciem w trybie przymusowym" $^{\text {"16. }}$ Z uwagi na bezpośrednie zaangażowanie wojska do akcji przesiedleńczej, oznaczało to wysiedlenie tych osób przez wojsko. Wysiedlano także osoby, które po wcześniejszym przesiedleniu do USRR, powróciły samowolnie lub z polskimi transportami, podając się za Polaków. Jako ciekawostkę można podać, że powrócili niektórzy mieszkańcy wsi Jaworki, którzy wcześniej dobrowolnie wyjechali. Wysiedlono także zdemobilizowanych żołnierzy Armii Czerwonej, którzy powrócili do swych rodzinnych miejscowości, traktując ich jak obywateli obcego państwa ${ }^{17}$. Było to o tyle niesprawiedliwe, że najpierw ich namawiano do wstąpienia $\mathrm{w}$ szeregi Armii Czerwonej lub ich zmuszono do tego, a teraz potraktowano ich jako obcokrajowców mimo, że nikt ich nie pozbawił obywatelstwa polskiego.

Udział wojska w akcji wysiedleńczej oznaczał dla ludności zmniejszenie się szans uniknięcia deportacji. Dlatego też chwytała się ona wszelkich sposobów, aby pozostać na dotychczasowym terenie. Salwowano się ucieczką do lasu lub sąsiedniej wsi, a nawet przechodzono granicę Czechosłowacką, przed zbliżającym się oddziałem wysiedleńczym. Po minięciu zagrożenia powracano do swych domostw. Tak na przykład zrobili

\footnotetext{
${ }^{15}$ AAN, GPRd/sF.LU, syg. 397/164. Sprawozdanie z przebiegu ewakuacji ludności ukraińskiej i innej do USRR, stan na dzień 15 sierpnia 1945 r.

${ }^{16}$ Repatriacja czy deportacja.., T. I, dok. 96, s. 231.

17 APK, UW, syg. 1082. Pismo MAP do wojewody krakowskiego w sprawie wysiedlenia zdemobilizowanych żołnierzy Armii Czerwonej i osób powracających z USRR z 31 grudnia 1945 r.
} 
mieszkańcy wsi Wisłok Wielki ${ }^{18}$. W dokumentach zachowała się informacja o około 2,5 tys. osób, które w obawie przed wysiedleniem przeszły na Słowacką stronę ${ }^{19}$, jednak zostali przekazani stronie polskiej, a ta skierowała je do USRR. Poza tym przekupywano osoby przeprowadzające wysiedlenie. Zapewniano władze o swej lojalności do państwa polskiego.

Przejście na obrządek rzymskokatolicki często wykorzystywała ludność, celem uniknięcia wysiedlenia. $\mathrm{Na}$ terenach mieszanych narodowościowo, właśnie obrządek określał przynależność narodową danej osoby, zgodnie ze schematem: rzymokatolik - Polak, grekokatolik lub prawosławny - Ukrainiec. Monitowano o tym władze wyższego szczebla. Ostatecznie władze centralne nakazały, aby wyznania nie utożsamiać z narodowością ${ }^{20}$. Władze lokalne jednak, przy określaniu narodowości nada brały pod uwagę wyznanie oraz niemieckie kenkarty (Ukraińcy miel wpisaną literę „U”), a także własne informacje. Najpewniejszym sposobem na uniknięcie wysiedlenia, było posiadanie obywatelstwa państw Zachodnich. Część Łemków takowe posiadała, uzyskując je w okresie pracy zarobkowej głównie w USA. Zgodnie z poleceniem władz centralnych, te osoby nie podlegały wysiedleniu ${ }^{21}$.

W odróżnieniu od pozostałej ludności podlegającej wysiedleniu kwestia określenia jej narodowości nastręczała władzom wielu trudności właśnie wśród Łemków. Nie wymienienie w układzie przesiedleńczym z 9 września 1944 r. narodowości łemkowskiej powodowało rozbieżności interpretacyjne. Część Łemków na tej podstawie uważała, że wspomniany układ ich nie obejmuje, zatem nie podlegają wysiedleniu. Innego zdania byli przedstawiciele władz, którzy zaliczyli ich do wymienionej w układzie

${ }^{18}$ M. Rodziński, 8 dywizja piechoty w walce z OUN-UPA (lipiec 1945-lipiec 1947), w: W walce ze zbrojnym podziemiem 1945-1947, Warszawa 1972, s. 66.

${ }^{19}$ Więcej na ten temat: „Obce pogranicze”1945-1946. Sytuacja w południowowschodniej Polsce w dokumentach czechosłowackich, red. M. Smigel, B. Halczak, R. Drozd, Warszawa 2015.

${ }^{20}$ AAN, MAP, syg. 781. Pismo MAP do UW w Krakowie w sprawie zmiany obrządku z 10 października 1945 r.

${ }^{21}$ APK, UW, syg. 1070. Pismo Głównego Przedstawiciela Rządu RP do Spraw Ewakuacji do Rejonowego Przedstawiciela Rządu RP do Spraw Ewakuacji w Nowym Sączu w sprawie nie wysiedlania osób posiadających obywatelstwo innych państw z 26 listopada 1945 r. 
narodowości „rusińskiej”. Celem rozwiania tych wątpliwości starostowie na obwieszczeniach przesiedleńczych starali się umieszczać także Łemków. Znany jest przypadek $\mathrm{z}$ powiatu gorlickiego, gdzie starosta zaaprobował wymienienie na obwieszczeniu Łemków Jednak już po wydrukowaniu obwieszczeń, słowo to zostało zamazane tuszem, gdyż nie było to zgodne z układem przesiedleńczym ${ }^{22}$.

Z zachowanych dokumentów wynika, że szczególną gorliwość w wyzbyciu się wszystkich Łemków z podległego sobie terenu, wykazywał wspomniany już starosta nowosądecki J. Łabuz, który, wbrew nakazowi MAP, wstrzymał się od podania do publicznej wiadomości postanowień umowy polsko-radzieckiej z 6 lipca 1945 r., dotyczącej prawa do zmiany obywatelstwa polskiego osób narodowości białoruskiej, litewskiej, rosyjskiej, rusińskiej i ukraińskiej zamieszkałej w Polsce i przesiedlenia się do ZSRR oraz zmiany obywatelstwa radzieckiego i przesiedlenia się do Polski osób narodowości polskiej i żydowskiej, zamieszkałych w ZSRR. Decyzję motywował tym, że „obywatel polski narodowości rosyjskiej czy ukraińskiej, zgodnie z umową będzie miał możność, lecz nie będzie musiał zmieniać swego obywatelstwa na radzieckie, to liczyć się należy, opierając się na dotychczasowej praktyce, że nikt $\mathrm{z}$ zainteresowanych podania o zmianę obywatelstwa polskiego na radzieckie nie wniesie, a jako taki będzie miał prawo żądać pozostawienia go w granicach RP" ${ }^{\text {23 }}$. Decyzję starosty poparł także wojewoda krakowski. 27 listopada 1945 r. Ministerstwo Administracji Publicznej zgodziło się na nie podawanie do wiadomości mieszkańców powiatu nowosądeckiego i nowotarskiego postanowień wspomnianej umowy ${ }^{24}$. J. Łabuz żądał także zwolnienia $\mathrm{z}$ pracy i wysiedlenia lekarza weterynarii w Krynicy Józefa Hawryluka, „gdyż jako Ukrainiec nie jest wraz z żoną na tutejszym terenie nadgranicznym pożądanym, tym bardziej, że zupełnie wystarczy jeden lekarz wet[erynarii] na dwa obwody do

\footnotetext{
${ }^{22}$ AAN, GPRd/sELU, sygn. 397/164. Pismo przedstawiciela rejonowego rządu RP do spraw przesiedlenia ludności ukraińskiej w Gorlicach do J. Bednarza w sprawie naniesienia zmian w treści obwieszczenia starosty gorlickiego z 29 lutego 1946 r.

${ }^{23}$ APK, UW, syg. 1070. Pismo starosty nowosądeckiego J. Łabuza do UW w Krakowie w sprawie prawa do zmiany obywatelstwa z 15 października 1945 r.

${ }^{24}$ Ibidem, Pismo MAP do wojewody krakowskiego w sprawie obwieszczeń o prawie zmiany obywatelstwa z 27 listopada 1945 r.
} 
urzędowego badania zwierząt rzeźnych i mięsa, tj. Krynicę i Muszynę"25. Także nieprzychylny był starosta nowotarski Skibiński, który opowiadał się za „wysiedleniem Łemków siłą przy pomocy wojska”26.

Obawa przed wysiedleniem powodowała, że zagrożona nim ludność pisała do najwyższych władz cywilnych jak i wojskowych petycje, w których domagała się pozostawienia na dotychczasowym terenie. Prośbę swą motywowano względami gospodarczymi, jak i lojalnością wobec państwa polskiego. Podkreślić należy, że w obronie wysiedlanych Łemków stanęli niektórzy przedstawiciele władz i partii politycznych szczebla lokalnego oraz duchowieństwa rzymskokatolickiego i miejscowej ludności polskiej. 15 września 1945 r. mieszkańcy gminy Komańcza, wraz z greckokatolickim duchowieństwem, wystosowali petycję do Ministerstwa Bezpieczeństwa Publicznego z prośbą o nieprzesiedlanie ich. Petycja została poparta przez Radę i Zarząd Gminy Komańcza ${ }^{27}$. Jednak na wniosek wojewody rzeszowskiego została rozpatrzona negatywnie. Ponownie wystosowano petycje 28 i 29 września do ministra bezpieczeństwa publicznego ${ }^{28}, 16$ lutego 1946 r. do ministra obrony narodowej ${ }^{29}$, a 18 lutego do premiera, ministrów obrony narodowej i sprawiedliwości oraz wojewody rzeszowskiego i starosty sanockiego $^{30}$. Powyższe działania Łemków uzyskały poparcie Powiatowej Międzypartyjnej Komisji Porozumiewawczej w Sanoku, która wystosowała do MAP memoriał domagając się w nim m.in.: „wstrzymania akcji wysiedleńczej $\mathrm{W}$ powiecie, natychmiastowego odsunięcia wojska od kierowania nią oraz przekazania całej inicjatywy w ręce władz administracji

${ }^{25}$ Repatriacja czy deportacja..., T. I, dok. 140, s. 298.

${ }^{26}$ AAN, GPRd/sKLU, syg. 397/162. Protokół z konferencji odbytej w gabinecie naczelnika Wydziału Społeczno- Politycznego UW w Krakowie w sprawie wysiedlenia Łemków z 7 maja 1946 r.

${ }^{27}$ AMSWiA, MAP, syg. 304. Petycja mieszkańców Gminy Komańcza do MBP z 15 września

$1945 \mathrm{r}$.

${ }^{28}$ Ibidem, Petycja ludności rusko-ukraińskiej z pow. sanockiego do MBP z 28 września $1945 \mathrm{r}$.

${ }^{29}$ AAN, GPR ds. ELU, syg. 397/164. Petycja sołtysów z gminy Komańcza z 16 lutego $1946 \mathrm{r}$.

${ }^{30}$ Ibidem, Petycja mieszkańców gminy Komańcza z 18 lutego 1946 r. 
ogólnej”’31. Również trzej mieszkańcy Krosna (L. Zajdel, J. Przybyła i inż. H. Wojtowicz) 29 marca 1946 r. w liście zbiorowym do wicepremiera i sekretarza generalnego KC PPR W. Gomułki poprosili o „humanitarne, ludzkie traktowanie pozostałych Łemków, zaprzestanie wyrafinowanych szykan, napadów i rabunków ze strony uzbrojonych band, a danie im zapewnienia spokojnej pracy, by teraz na wiosnę pola nie leżały odłogiem i wskutek tego powstał w naszych stronach głód"32.

Petycje ludności oraz władz lokalnych spowodowały, że 1 kwietnia 1946 r. Główny Przedstawiciel Rządu RP do Spraw Ewakuacji zwrócił się do Polskiej Akademii Umiejętności z prośbą o określenie narodowości Łemków. 16 kwietnia nadeszła odpowiedź, w której stwierdzono, że Łemkowie „sa taką samą ludnością ruską, jak rdzenna ludność b. wschodniej Galicji, [...] mówią dialektem nieco odrębnym od literackiego języka ukraińskiego, ale znacznie bliższym jemu niż polskiemu. Narodowo zawsze uważali się za „Rusinów”, a kiedy przed półwieczem cała ludność ruska b. wschodniej Galicji uświadomiła się i zadeklarowała jako naród „ukraiński”, konserwatywni Łemkowie pozostali przy swojej starej nazwie Rusinów czy Rusnaków i okazywali przychylność partii staroruskiej, wzdychającej do połączenia się z jednym wielkim nierozdzielnym narodem rosyjskim. $\mathrm{Z}$ tego wynikało, że choć w stosunku do Polaków mniej szowinistyczni od nacjonalistycznych Ukraińców, mimo to wcale a wcale nie uważali się za Polaków, ale za część nierozdzielnego narodu ruskiego; w ostatnich czasach jednak wpływy ukraińskie rosły. Nigdy też przy wyborach Łemkowie nie głosowali na kandydatów polskich, nawet chłopskich, a w czasie okupacji hitlerowskiej nigdy się jej nie narażali. Jeżeli więc teraz „uważają się za Polaków", to wyłącznie dlatego, że chcą zostać w Polsce. Jest to polskość

${ }^{31}$ AMSWiA, MAP, syg. 304. Memoriał Powiatowej Międzypartyjnej Komisji Porozumiewawczej w Sanoku do MAP w sprawie przesiedlenia ludności ukraińskiej z 6 października $1945 \mathrm{r}$.

${ }^{32}$ Repatriacja czy deportacja..., t. 2, dok. 32. List mieszkańców Krosna do W. Gomułka w związku z przymusowym wysiedleniem Łemków z 29 marca 1946 r., s. 75-78. 
najzupełniej koniunkturalna, szczera chyba u nielicznych tam rzymskich katolików"33.

Dnia 19 kwietnia 1946 r. I sekretarz rządzącej partii Polskiej Partii Robotniczej Władysław Gomułka, który w 1942 r. ukrywał się wśród Łemków i uczestniczył w naradach Okręgu Podkarpackiego PPR-GL w mieszkaniu Michała Dońskiego, w piśmie do wiceministra administracji publicznej Władysława Wolskiego prosił o natychmiastowe wydanie właściwym instytucjom poleceń surowo zabraniających stosowania przymusu przy wysiedlaniu Łemków. 24 kwietnia MAP nakazało wojewodzie krakowskiemu stosowanie zasady dobrowolności przy wysiedlaniu Łemków. Jednocześnie, wyraziło zgodę na pozostawienie w granicach Państwa Polskiego elementu lojalnego wobec Państwa oraz przyznającego się do narodowości polskiej”, zwłaszcza rodziny mieszane ${ }^{34}$. Niemniej wojewoda krakowski informując o decyzji władz centralnych starostę nowosądeckiego i nowotarskiego, nakazał ścisłe wykonanie postanowień konferencji przedstawicieli wojska, Urzędu Wojewódzkiego oraz nowotarskich i nowosądeckich władz powiatowych i przesiedleńczych z 7 maja $1946 \mathrm{r}^{35}$. Postanowiono na niej, aby w miesiącu maju wysiedlić $\mathrm{z}$ powiatu nowotarskiego 370 osób, a nowosądeckiego 2200 osób $^{36}$. Fakt ten świadczy niezbicie o dążeniu niektórych przedstawicieli władz lokalnych do wyzbycia się Łemków. Z zachowanych dokumentów wynika, że jednak część $\mathrm{z}$ tej ludności uniknęła wysiedlenia ${ }^{37}$.

Ogółem według danych oficjalnych (można je traktować tylko orientacyjnie) wysiedlono około 95 tys. Łemków, z czego z powiatu Gorlice ponad 15 tys. osób (pozostało 2 tys. osób), Jasło - ponad 7 tys. osób

33 AAN, GPRd/sELU, syg. 397/164. Pismo PAIJ do Głównego Przedstawiciela Rządu RP do Spraw Ewakuacji Ludności Ukraińskiej w Lublinie w sprawie przynależności narodowej Łemków z 16 kwietnia 1946 r.

${ }^{34}$ APK, UW, syg. 1082. Pismo UW w Krakowie do starosty nowosądeckiego w sprawie wysiedlenia ludności ukraińskiej z 7 maja 1946 r.

${ }^{35}$ Ibidem.

${ }^{36}$ AAN, GPRd/sELU, syg. 397/162. Protokół z konferencji odbytej w gabinecie naczelnika Wydziału Społeczno- Politycznego UW w Krakowie w sprawie wysiedlenia Łemków z 7 maja 1946 r.

${ }^{37}$ Repatriacja czy deportacja..., T. II. dok. 87, s. 180. 
(pozostało - ponad 300), Krosno - ponad 11 tys. osób (pozostało ok. 100), Nowy Sącz - ponad 17,7 tys. (pozostało ponad 4,7 tys.), Nowy Targ - ponad 1,8 tys. (pozostało ok. 250 osób), Sanok - ok. 42 tys. (pozostało ponad 7,8 tys. $)^{38}$. Wysiedlono także hierarchów greckokatolickiej diecezji przemyskiej ordynariusza Jozafata Kocyłowskiego oraz jego sufragana Hryhorija Łakotę oraz większość księży. Akcją objęto także księży greckokatolickich z Apostolskiej Administracji Łemkowszczyzny, utworzonej w 1934 r. z części greckokatolickiej diecezji przemyskiej i obejmującą tereny zachodniej Łemkowszczyzny oraz niemal wszystkich księży prawosławnych z tamtego terenu ${ }^{39}$.

Po zakończeniu wysiedlenia na Ukrainę Radziecką, władze zorientowały się, że część ludności ukraińskiej pozostała. Z początkiem 1947 r. ich liczbę oceniano na ponad 20 tys. osób, gdy w rzeczywistości było około 200 tys. Ukraińców, w tym 30-35 tys. Łemków (według danych oficjalnych miało być ich ponad 15 tys.). Początkowo zwrócono się do władz radzieckich z propozycja kontynuowania wysiedlenia z Polski Do Związku Radzieckiego, ale władze radzieckie odmówiły, godząc się jedynie na indywidualne przesiadlenie się rodzin. Odmowa wynikała z faktu, że w większości aparat przesiedleńczy został przeniesiony na Słowację, celem przesiedlenia tamtejszych Rusinów ${ }^{40}$. W tej sytuacji władze, kierując się dążeniem do zbudowania jednonarodowej Polski, postanowiły pozostałą ludność ukraińską wysiedlić na ziemie zachodnie i północne Polski. Przygotowania do nowej akcji deportacyjnej, która otrzymała kryptonim „Akcja «Wisła»”, rozpoczęły się z początkiem 1947 r. Akcją zaplanowano objąć „wszystkie odcienie narodowości ukraińskiej”, czyli także Łemków $^{41}$. Z propozycją wysiedlenia tych ostatnich wystąpił 14 lutego 1947 r. również starosta nowotarski Leon Leja, który w piśmie do Wydziału Społeczno-Politycznego Urzędu Wojewódzkiego w Krakowie postulował: „Aby stworzyć graniczne

\footnotetext{
${ }^{38}$ CAW, Sztab Generalny WP, syg. IV111.511. Sprawozdanie z przebiegu akcji ewakuacyjnej ludności ukraińskiej do USRR od 15 X 1944 r. do 5 VII 1946 r.

${ }^{39}$ Patrz: Hałagida I., Między Moskwą, Warszawą i Watykanem. Dzieje Kościoła greckokatolickiego w Polsce w latach 1944-1970, Warszawa 2013.

${ }^{40}$ Fakt ustalony przez Michala Smigela i przedstawiony na I Sympozjum Karpackim w Starej Lesnej w 2017 r.

${ }^{41}$ Patrz: Pisuliński J., Akcja specjalna „Wisła”, Rzeszów 2020.
} 
powiaty czysto polskimi, co leży zresztą $\mathrm{w}$ interesie państwa, $\mathrm{i}$ aby usunąć kwestię Łemków $\mathrm{z}$ zagadnień polityki polskiej, wskazanym byłoby przesiedlenie Łemków w głąb Polski. Takie załatwienie tej kwestii pozbawiłoby równocześnie nacjonalistyczne bandy ukraińskie baz wypadowych i moralnego oparcia przyjaznych im elementów" propozycją wysiedlenia Łemków $\mathrm{z}$ powiatu nowosądeckiego wystąpił dowódca Okręgu Wojskowego V gen. Mikołaj Więckowski ${ }^{43}$.

Dnia 27 marca 1947 r. na posiedzeniu Państwowej Komisji Bezpieczeństwa powierzono ministrowi bezpieczeństwa publicznego Stanisławowi Radkiewiczowi zadanie ,poruszenia z odpowiednimi czynnikami” sprawy wysiedlenia Ukraińców ${ }^{44}$. W tym też dniu Wydział Operacyjny Oddziału III Sztabu Generalnego WP postulował ,przeprowadzić energiczną akcję przesiedleńczą tych ludzi pojedynczymi rodzinami na teren Ziem Odzyskanych, gdzie mogą się szybko zasymilować" ${ }^{45}$. Dzień później w zasadzce UPA pod Jabłonką zginął, w niewyjaśnionych do dzisiaj okolicznościach, wiceminister Obrony Narodowej gen. Karol Świerczewski. Jego śmierć stała się pretekstem, doskonale wykorzystanym przez władze, do usprawiedliwienia planowanych niehumanitarnych działań wobec ludności ukraińskiej. Od tego momentu rozpętano na masową skalę antyukraińską propagandę, w której przedstawiano Ukraińców jak głównego wroga Polaków i Polski. 29 marca 1947 r. Biuro Polityczne KC PPR w składzie: Władysław Gomułka, Bolesław Bierut, Roman Zambrowski, Jakub Berman, Hilary Minc, Stanisław Radkiewicz, Marian Spychalski i Aleksander Zawadzki, postanowiło przeprowadzić akcję wysiedleńczą ludności

${ }^{42}$ APK, UW, syg. 1081. Pismo starosty nowotarskiego Leona Leji do UW w Krakowie w sprawie przesiedlenia Łemków z 14 lutego 1947 r.

${ }^{43}$ Centralne Archiwum Wojskowe (CAW), Sztab Generalny WP, syg. IV111.470. Sprawozdanie sytuacyjne Dowództwa Okręgu Wojskowego V za luty 1947 r. z 6 marca $1947 \mathrm{r}$.

${ }^{44}$ „Akcja „Wisła”. Dokumenty, opr. E. Misiło, Warszawa 1993, dok. 15. Protokół nr 19 posiedzenia Państwowej Komisji Bezpieczeństwa z 27 marca 1947 r., s. 59-61.

45 CAW, Sztab Generalny WP, syg. IV11 1.471. Charakterystyka stanu bezpieczeństwa kraju w okresie od 1 do 25 marca 1947 r. opracowana przez Wydział Operacyjny Oddziału 111 Sztabu Generalnego WP z 27 marca 1947 r. 
ukraińskiej ${ }^{46}$. Podkreślmy, że decyzję podjęło kierownictwo partii politycznej, a nie rząd. Od tego momentu rozpoczęły się intensywne przygotowania. Ostatecznie 24 kwietnia 1947 r. Prezydium Rady Ministrów podjęło uchwałę $\mathrm{W}$ sprawie przeprowadzenia akcji „Wisła”. W świetle zachowanych dokumentów temu zamierzeniu przyświecały dwa cele: pierwszy doraźny - likwidację oddziałów UPA dzięki wysiedleniu ludności i drugi - perspektywiczny - ostateczne rozwiązanie problemu ukraińskiego poprzez asymilację Ukraińców w nowym miejscu osiedlenia.

Dnia 28 kwietnia 1947 r., specjalnie dla tego celu utworzona Grupa Operacyjna „Wisła” w sile ponad 21 tys. żołnierzy, rozpoczęła deportację ludności ukraińskiej na ziemie zachodnie i północne Polski. Akcję realizowano $\mathrm{w}$ trzech etapach. W pierwszym objęto głównie powiaty województwa rzeszowskiego, a w następnych także woj. krakowskiego i lubelskiego. Na Łemkowszczyźnie akcję rozpoczęto 28 kwietnia. Właśnie transport z Łemkami ze stacji Szczawne-Kulaszne był jednym z dwóch pierwszych transportów jakie skierowano na ziemie zachodnie i północne Polski, a dokładnie do powiatu człuchowskiego i słupskiego. Masowość akcji ustała wraz z rozwiązaniem w ostatnim dniu lipca GO „Wisła”. Wynikało to Z wysiedlenia prawie wszystkich Ukraińców, czyli ponad 140 tys. osób, w tym około 30 tys. Łemków. Nie oznaczało to jednak, że zaprzestano wysiedleń. Trwały one jeszcze w następnych latach i obejmowały także rodziny, które nielegalnie powróciły. Te ostatnie do końca 1947 r. były kierowane do Centralnego Obozu Pracy w Jaworznie. Trafiały tam też osoby, które władze podejrzewały o związki z podziemiem ukraińskim lub które mogły mieć wiedzę na jego temat. Ogółem osadzono tam ponad 3800 osób, w tym kobiety, dzieci oraz 22 duchownych greckokatolickich oraz 5 prawosławnych. Wśród osadzonych byli także Łemkowie. W wyniku złych warunków bytowych, chorób, tortur życie straciło co najmniej 161 osób. Zdecydowana większość więźniów była niewinna.

Ostatni znany nam transport z Łemkowszczyzny w ramach akcji „Wisła” przybył do województwa szczecińskiego w kwietniu 1950 r.

\footnotetext{
${ }^{46}$ AAN, KC PPR, syg. 295/V-3. Protokół nr 3 z posiedzenia Biura Politycznego KC PPR z 29 marca 1947 r.
} 
Znalazły się w nim 34 rodziny z miejscowości: Szlachtowa, Jaworki, Biała Woda i Czarna Woda ${ }^{47}$.

Łemków rozproszono po całych ziemiach zachodnich i północnych, przy czym najwięcej osiedlono ich na Dolnym Śląsku i Ziemi Lubuskiej, w większości w zrujnowanych gospodarstwach, gdyż te lepsze były już zajęte przez wcześniej przybyłych osadników polskich. Obejmowały ich te samy zakazy i obostrzenia co i pozostałą ludność ukraińską. Zakazano im organizowania życia narodowego i religijnego. Osiedlano w rozproszeniu tak, aby nie tworzyli zwartych grup i nie przekraczali 10\% mieszkańców powiatu. Władze zakazały rozmieszczania rodzin ukraińskich w strefach: 50 $\mathrm{km}$ od granic lądowych, $30 \mathrm{~km}$ od granic morskich i miast wojewódzkich oraz $10 \mathrm{~km}$ od zachodniej granicy Polski z 1939 r. MBP nakazywało, aby w jednej wsi umieszczać tylko jedną rodzinę zaliczoną do grupy „A” (rodziny, których członkowie mogli być w UPA) lub „B” (rodziny, które mogły współpracować z UPA) i do pięciu rodzin z grupy „C” (pozostałe rodziny). Rodziny z kategorii „A” i „B” nie mogły być osiedlane razem oraz z rodzinami $\mathrm{z}$ kategorii „C”. Identyczne zasady obowiązywały przy umieszczaniu Ukraińców w majątkach państwowych i parcelacyjnych ${ }^{48}$. Zasady te $w$ praktyce były niemożliwe do realizacji ze względu na liczbę rodzin ukraińskich. $Z$ tego powodu władze w listopadzie 1947 r. nieco zmodyfikowały powyższe zasady. Zakazano osiedlania w $30 \mathrm{~km}$ pasie nadgranicznym lądowym, $10 . \mathrm{km}$ morskim i $20 . \mathrm{km}$ strefie od miast wojewódzkich. Podniesiono jednocześnie liczbę mogących być osiedlonych

${ }^{47}$ AAN, MAP, syg. 781. Pismo UW w Krakowie do MAP z 29 kwietnia 1950 r. Istnieje podejrzenie, że wśród tych rodzin byłe także te, które przesiedliły się do USRR, następnie nielegalnie powróciły i zostały objęte akcją „Wisła”, by znów nielegalnie powrócić i znów zostać deportowanym. Znany jest przykład malarzaprymitywisty Epifanija Drowniaka (Nikifor), który co najmniej dwa razy był wysiedlany i za każdym razem powracał do swej ukochanej Krynicy.

${ }^{48}$ Archiwum Państwowe we Wrocławiu (APW), UW, syg. IX/270. Instrukcja MZO dotycząca zasad rozmieszczania osadników z akcji „Wisła” z 31 lipca 1947 r.; R Drozd, Zasady rozmieszczania ludności ukraińskiej na Ziemiach Odzyskanych w ramach akcji „Wisła”, „Słupskie Studia Historyczne” 1993, nr 3, s. 104-106. 
Ukraińców w jednej wsi do 40\% ogółu mieszkańców. Nie należało jednak przekraczać $10 \%$ odsetka Ukraińców w powiecie ${ }^{49}$.

Powyższe normy osadnicze zostały następnie przesłane zainteresowanym urzędom wojewódzkim, $\mathrm{z}$ poleceniem dostosowania do nich rozmieszczenia Ukraińców. Zastrzeżono jednak, że „dokonywanie wewnętrznych przesunięć osadników z akcji „W” może być wykonywane $\mathrm{W}$ zakresie najkonieczniejszym, w wypadkach szczególnie uzasadnionych i przy uwzględnieniu całokształtu niniejszych zasad" ${ }^{50}$. Oznaczało to i tak konieczność ponownego przesiedlenia kilka tysięcy rodzin. $\mathrm{Z}$ dokumentów wynika, że takie przesunięcia planowano dokonać wiosną $1948 \mathrm{r}$. Najpełniejszy ich obraz mamy właśnie z ówczesnego województwa wrocławskiego. Przesunięć dokonano w okresie od kwietnia do lipca 1948 r. Wówczas 52 rodziny z powiatu Oława skierowano do pow. Strzelin, z pow. Środa Śląska przesiedlono 31 rodzin do pow. Jawor i 5 rodzin do pow. Świdnica, z pow. Oleśnica wysiedlono 56 rodzin z czego 23 rodziny osiedlono w pow. Świdnica, 20 w pow. Złotoryja i 13 w pow. Żagań, z pow. Oleśnica przerzucono 55 rodzin do pow. Bolesławiec, do którego skierowano także 46 rodzin z pow. Trzebnica. $Z$ tego ostatniego wysiedlono 51 rodzin, lecz nie udało się ustalić do jakiego powiatu je skierowano ${ }^{51}$.

Podsumowując należy stwierdzić, że wysiedlenia ludności łemkowskiej, jak i wszystkich Ukraińców, były następstwem polityki narodowościowej komunistycznych władz polskich ${ }^{52}$. Dążyły one do przekształcenia Polski w państwo jednonarodowe. Podstawowym sposobem na osiągnięcie tego celu było zmuszenie mniejszości narodowych do wyjazdu z Polski, a wobec tych co pozostali zastosowanie działań asymilacyjnych. W przypadku ludności ukraińskiej stwierdzono wprost: „zasadniczym celem przesiedlenia osadników «W» jest ich asymilacja w nowym środowisku

49 AAN, MAP, syg. 781. Instrukcja MZO dotycząca zasad rozmieszczania osadników z akcji „Wisła” z 10 listopada 1947 r.

${ }^{50}$ Ibidem.

51 R. Drozd, Droga na zachód. Osadnictwo ludności ukraińskiej na ziemiach zachodnich i północnych Polski w ramach akcji „Wisła”, Warszawa 1997, s. 123 124.

52 Patrz: Drozd R., Polityka władz wobec ludności ukraińskiej w Polsce w latach 1944-1989, Warszawa 2001. 
polskim. Dołożyć należy wszelkich wysiłków, aby cel ten był osiągnięty. Nie używać w stosunku do tych osadników określenia «Ukrainiec». W wypadku przedostania się $\mathrm{z}$ osadnikami na Ziemie Odzyskane elementu inteligenckiego, należy taki bezwzględnie umieszczać osobno i z dala od gromad, gdzie zamieszkują osadnicy z akcji «W»"53.

\section{BIBLIOGRAFIA}

„Akcja „Wisła”. Dokumenty, opr. E. Misiło, Warszawa 1993

Deportacji. Zachidni zemli IJkrajiny kincia 30-ch - początku 50-ch rr. Dokumenty, materiały, spohady. T. I. 1939-1945 rr., Lviv 1996

Drozd R., Droga na zachód. Osadnictwo ludności ukraińskiej na ziemiach zachodnich i północnych Polski w ramach akcji „Wisła”, Warszawa 1997

Drozd R., Polityka władz wobec ludności ukraińskiej w Polsce w latach 1944-1989, Warszawa 2001

Drozd R., Zasady rozmieszczania ludności ukraińskiej na Ziemiach Odzyskanych w ramach akcji „Wisła”, „Słupskie Studia Historyczne" 1993, nr 3

Halczak B., Dzieje Łemków od średniowiecza do czasów współczesnych, Warszawa 2014

Hałagida I., Między Moskwą, Warszawą i Watykanem. Dzieje Kościoła greckokatolickiego w Polsce w latach 1944-1970, Warszawa 2013.

Kozłowśkyj I., Wstanowłennia ukrajinśko-polśkoho kordonu 1941-1951 rr. Lviv 1998

„Obce pogranicze"1945-1946. Sytuacja w południowo-wschodniej Polsce w dokumentach czechosłowackich, red. M. Smigel, B. Halczak, R. Drozd, Warszawa 2015.

Pisuliński J., Akcja specjalna „Wisła”, Rzeszów 2020

Pisuliński J., Przesiedlenie ludności ukraińskiej z Polski do USRR w latach 1944-1946, Rzeszów 2017.

53 AAN, MAP, syg. 781. Instrukcja MZO dotycząca zasad rozmieszczania osadników z akcji „Wisła” z 10 listopada 1947 r. O polityce względem Ukraińców patrz: R Drozd, Polityka władz wobec ludności ukraińskiej w Polsce w latach 19441989, Warszawa 2001. 
Repatriacja czy deportacja. Przesiedlenie Ukraińców z Polski do USRR 1944-1946. T. I. Dokumenty 1944-1945. Pod red. E. Misily, Warszawa 1996, s. 11.

Repatriacja czy deportacja. Przesiedlenie Ukraińców z Polski do USRR 1944-1946. T. II. Dokumenty 1946. Pod red. E. Misily, Warszawa 1999

Rodziński M., 8 dywizja piechoty w walce z OUN-UPA (lipiec 1945-lipiec 1947), w: W walce ze zbrojnym podziemiem 1945-1947, Warszawa 1972

Szczęśniak A.B., Szota W.Z., Droga do nikąd. Działalność Organizacji Ukraińskich Nacjonalistów i jej likwidacja w Polsce, Warszawa 1973

Roman Drozd

DISPLACEMENT ACTIONS OF UKRAINIANS-LEMKOS IN POLAND IN 1944-1950

Summary

The displacement of the Lemko population and all Ukrainians living in Poland in the years 1944-1950 was a consequence of the national policy of the communist Polish authorities. Their goal was to transform Poland into a mono-national state. The basic way to achieve this goal was to force national minorities to leave Poland and to apply assimilation measures to the rest. That is why, in 1947, the operation "Vistula" was carried out, as part of which the remaining Ukrainian-Lemkos were deported to the western and northern territories of Poland and assimilated.

Keywords: Ukrainians, Lemkos, deportations, Poland 1944-1950 